\title{
SOCIO-ECONOMIC MORTALITY DIFFERENCES IN THE NETHERLANDS IN 1950-1984: A REGIONAL STUDY OF CAUSE-SPECIFIC MORTALITY
}

\author{
A. E. Kunst, C. W. N. Looman and J. P. Mackenbach \\ Department of Public Health and Social Medicine. Erasmus University, P.O. Box 1738 , \\ 3000 DR Rotterdam, The Netherlands
}

\begin{abstract}
The finding that mortality differences between occupational classes in England and Wales have widened during the postwar period raises the question whether a similar development has occurred in other industrialised countries. In this paper, a comparison is made with results from a geographical study on the Netherlands. This study compares four periods between 1950 and 1984 by means of a standard regional division, a single socio-economic index, uniform cause-of-death groups and a standard regression procedure. During the postwar period, the relationship between socio-economic level and all-cause mortality has become (more) negative. This development can to a large extent be attributed to 'negative' trends for lung cancer, diabetes mellitus, ischaemic heart disease, cerebrovascular disease and traffic accidents. High-level regions have fared better partly because favourable changes in national mortality trends seem to have begun first in these regions. The findings from this regional study agree to a large extent with evidence from Dutch studies at the individual level. It is concluded that socio-economic mortality differences in England and Wales and the Netherlands have probably developed similarly in various respects.
\end{abstract}

Key words-socio-economic differences. mortality, causes of death, trends

\section{INTRODLCTION}

In the 1960s and 1970s, studies that demonstrated the persistence of socio-economic mortality differences in highly developed countries $[1,2]$ hardly affected the widely held illusion that such differences were disappearing under the welfare state [3,4]. During the last decade, however, it became ever more widely acknowledged that mortality and socio-economic position are still strongly associated [5,6]. The current wide interest has in particular focussed on the United Kingdom, where the authors of the Black Report argued that mortality differences between occupational classes have widened, and used this argument in a plea for a radical reorientation in health policy [7]. The question whether mortality differences have indeed widened in the U.K. became the subject of a heated discussion [8-10]. but detailed studies made it plausible that this really is what happened [11-13].

The widening mortality differentials are intriguing but at the same time difficult to explain. Some insights have been derived from studies of specific causes of death, which are possible in England and Wales thanks to the unique set of data from subsequent Decennial Supplements [14]. Mortality differentials for specific causes of death appeared to develop according to different patterns [12.15]. These patterns are illustrated in Table I for the postwar period:

-Strong inverse (negative) gradients which existed in 1951 have not been reduced and have even sometimes become wider; this pattern was followed by stomach cancer. influenza and pneumonia, chronic obstructive lung disease (COLD) and also perinatal mortality [16].
-Positive gradients for males and weak inverse gradients for females have gradually turned into strong inverse gradients; a classic example of a former 'disease of affluence' is ischaemic heart disease [17], but the same pattern is followed by lung cancer [18], diabetes mellitus, hypertensive disease and cerebrovascular disease (CVA).

-For other causes of death, changes in gradients have been small and/or irregular; examples are breast cancer and traffic accidents for which a class gradient emerged in the 1950s which hardly changed in later years.

The widening differences in total mortality can to a large extent be attributed to the second pattern of development, because this applied to several of the largest causes of death.

Studies of specific causes of death also pointed to the role of a number of determinants. For example, Marmot showed that the reversal for ischaemic heart disease from a high-class disease to a lower-class disease occurred when the higher classes began to consume less tobacco and sugar, and eat more wholemeal bread in comparison to the lower classes [19]. Hems argued that the positive class gradient for breast cancer had virtually disappeared in the 1950s because in the early 1940s fat and animal protein consumption rose among the lower classes while it declined among the higher classes. These trends in consumption patterns were related to the onset of food rationing at the beginning of the Second World War [20]. Other cause-specific studies based on Decennial Supplement data concerned causes of death which have become amenable to medical intervention $[12,21]$. including perinatal mortality [16]. 
Table 1. Development of class differences in cause-specific mortality in England and Wales since 195!

\begin{tabular}{|c|c|c|c|c|c|c|c|c|}
\hline \multirow[b]{3}{*}{ Cause of death } & \multicolumn{8}{|c|}{$100 \cdot$ SMR class II $(=$ high $)$ SMR IV $(=$ low $)$} \\
\hline & \multicolumn{4}{|c|}{ Males" } & \multicolumn{4}{|c|}{ Married females* } \\
\hline & 1951 & 61 & 71 & 81 & 1951 & 61 & 71 & 31 \\
\hline Total mortalityt & 94 & 79 & 71 & 66 & 87 & 79 & 73 & 66 \\
\hline Stomach cancert & 64 & 55 & 53 & 53 & 75 & 69 & 68 & 62 \\
\hline Colon cancert & 112 & 108 & 100 & 98 & 105 & 99 & 83 & 99 \\
\hline Lung cancert & 92 & 69 & 55 & 50 & 99 & 88 & 66 & 53 \\
\hline Breast cancer ${ }^{+}$ & 101 & 114 & 109 & $\ddagger$ & 133 & 108 & 109 & 98 \\
\hline Prostate cancert & 109 & 111 & 84 & 107 & \multicolumn{4}{|c|}{ not applic. } \\
\hline Diabetes mellitus & 118 & 105 & 84 & 62 & 66 & 55 & 41 & 70 \\
\hline Hypertensive diseatse & 128 & 100 & 76 & 53 & 76 & 65 & 55 & 45 \\
\hline Ischaemic heart disease & 139 & 99 & 84 & 73 & 92 & 76 & 63 & +4 \\
\hline Other heart disease & 81 & 75 & 62 & 65 & 59 & 52 & 55 & 56 \\
\hline Cerebrovascular disease & 118 & 91 & 77 & 62 & 94 & 74 & 68 & 57 \\
\hline Arterial diseases & 102 & 72 & 79 & 92 & 60 & 48 & 67 & 55 \\
\hline Influenza and preumonia & 61 & 53 & 46 & 41 & 65 & 61 & 51 & 49 \\
\hline COLDS & 52 & 43 & 40 & 36 & 40 & 43 & 46 & 42 \\
\hline Motor vehicle accidents & 86 & 73 & 69 & 67 & 109 & 86 & 96 & 83 \\
\hline
\end{tabular}

-Age group 15-64 years, except for 1951 (20-64 years) and 1981 (males 20-64 years, and females 20-59 years).

Married women are classified according 10 their husband's occupation.

tFigures for 1951 have been taken from Logan [18], who corrected them for misclassification of company directors.

+No data available.

\$Data for 1951 and 1961 refer to bronchitis.

The fact that for several of these causes class gradients have widened since 1951 suggests that differences in access to/use of/quality of medical care may also have contributed to the widening of the mortality gap between social classes.

The prominent role of data from England and Wales in all these discussions raises the question whether a widening of socio-economic differences in total mortality, and the underlying trends for specific causes of death, is a uniquely English phenomenon or has occurred in other highly developed countries as well. With respect to all-cause mortality, socioeconomic differences have probably also widened in France [22], Hungary [23] and the United States [24], but not in Scandinavian countries [25]. Socioeconomic differences in perinatal mortality were found to persist in various countries [2], although these differences have often been reduced [25-27]. Evidence on other causes of death is limited. A reversal in the mortality gradient for ischaemic heart disease occurred in the United States $[28,29]$ and more recently also in Finland [30], but could not be shown for France [22] or Hungary [23]. For both France [22], Hungary [23] and the U.S. [31], socioeconomic differences in cancer mortality have probably become less positive or more negative. A similar development was observed for diabetes mellitus in Hungary [23] and in the U.S. [31], and for cerebrovascular diseases in the U.S. [31]. Opposite trends or no clear trends were observed in these countries for respiratory diseases $[23,31]$ and accidents $[22,23,31]$. Thus, available evidence corroborates the findings on England and Wales to some extent, but is too scarce to permit definitive conclusions.

This paper will deal with the question whether socio-economic mortality differentials in another country, the Netherlands, have developed in a similar way as in England and Wales. We will first examine the evidence from previous studies on socioeconomic mortality differences in this country, and then present the results of a new analysis using regional data.
Review of previous studies on socio-economic mortality differentials in the Netherlands

Table 2 summarises the main characteristics and results of studies on male all-cause mortality in the Netherlands since 1945. In all studies, the highest socio-economic group appeared to experience the lowest death rates. In studies from the 1950s and the early 1960 s, however, mortality differences by occupational class were small and inconsistent, with white collar workers having higher mortality risks than labourers [32-34]. In contrast, studies concerning the post- 1965 period found more consistent and larger mortality differences [35-38]. Although differences between findings from earlier and later studies may be attributable to random error, different study designs or particularities of the study populations, they are also consistent with the hypothesis that all-cause mortality differences have widened in the Netherlands in the postwar period.

Perinatal mortality risks were negatively associated with the socio-economic position of parents in national studies from 1952 to 1953 [39] and 1961 [40]. A recent study in Amsterdam did however not find consistent differences [41], which suggests that perinatal mortality differences may have been reduced.

A comparison of studies further suggests that occupational class differences in ischaemic heart disease mortality changed from a positive gradient to an inverse gradient during the $1960 \mathrm{~s}$. For the period 1947-61, Schrama found a consistent increase of mortality rates from lower to higher occupational groups among men employed in a state company [33]. A national study still found a positive, but weak and inconsistent class gradient in cardiac mortality in 1959-1961 [34], but a study on a sample of men from Rotterdam observed the highest cardiac death rates among lower occupational classes in 1972-1983 [38]. A consistently negative mortality gradient for ischaemic heart disease was observed in a follow up of the 1932 birth cohort from 1948 to 1981 (ischaemic heart disease mortality in this cohort occurred mainly in the late 1960s and 1970s) [36]. 
A similar reversal may have occurred for lung cancer. While death rates were still positively related to occupational status in the Netheriands in the 1930s [42] and in an Amsterdam hospital in the 1940s [43], the national study of 1959-61 found the highest mortality rates among labourers [34].

Doornbos observed that members of the 1932 birth cohort in the lowest educational groups died considerably more often from external causes of death, and slightly more often from neoplasms [36]. There are no data to establish trends in mortality differences for these causes. The same applies to the remaining causes of death. Individual-level data on mortality differences among women are even completely nonexistent in the Netherlands.

In addition to individual-level studies, a number of geographical studies has been performed, in which socio-economic indicators were related to mortality rates for regions or inner-city areas [44]. The most important example is a comparative study of neighbourhoods in Amsterdam in 1972-1976, which was undertaken at a time when practically all that was known about socio-economic mortality differences in the Netherlands was thought to be outdated [45]. The unexpected observation of higher mortality in deprived areas was considered to be an indication that socio-economic mortality differences still persisted in the Netherlands. Although such a crosslevel inference is subject to the risk of 'ecological fallacy' [46], the suggestion derived from this study partly filled the gap in knowledge on socio-economic mortality differences, and led to individual-leve! studies which yielded results which were generally in agreement with those from this ecological study [35-38].

In this paper, we will also use geographical data, as these data permit the study of the evolution of differential mortality over time. for all-cause mortality as well as for mortality from specific causes of death. For the period 1950-1984, we will relate cause-specific mortality levels in Dutch regions to the socio-economic characteristics of their inhabitants.

\section{DATA AND METHODS}

The analysis to be reported here concerns four 5-year periods (1950-54, 1960-64, 1970-74 and $1980-84)$ and 39 nodal regions with a median population size of about 300,000 inhabitants in recent years (a 40th region, consisting of recently reclaimed and inhabited land, has been excluded from the analysis). The 5-year periods will be denoted here by their central years (1952 etc.).

Mortality data by age, sex, cause of death (ICD 4-digit codes), region of residence and year of death were supplied by the Dutch Central Bureau of Statistics. ICD 4-digit codes were combined in such a way that the resulting cause-of-death groups were maximally comparable across the four ICD Revisions under operation in the study period. The analysis is restricted to causes of death which were among the largest 10 causes in 1950-54 and or 1980-84 among males and/or females. This selection (presented in Table 3) includes both causes of death with increasing death rates and causes with decreasing rates. Overall regional mortality differences were not statistically

Table 2. Male alt-cause mortality according to socio-economic group in the postwar period in the Netherlands: results of studies at the individual level

\begin{tabular}{|c|c|c|c|c|c|}
\hline $\begin{array}{l}\text { Author } \\
\text { [Ref.] }\end{array}$ & $\begin{array}{l}\text { Study } \\
\text { design }\end{array}$ & $\begin{array}{l}\text { Period. } \\
\text { age group* }\end{array}$ & Population & Socio-economic group & $\begin{array}{c}\text { Relative } \\
\text { risk+ }\end{array}$ \\
\hline $\begin{array}{c}\text { Wolff } \\
{[32]}\end{array}$ & Cross-sectional & $1947-52,15-64$ & $\begin{array}{l}\text { Total } \\
\text { Amsterdam } \\
\text { population } \\
(N \approx 300,000)\end{array}$ & $\begin{array}{l}\text { Professionals, managers a.o. } \\
\text { Own account workers } \\
\text { Lower employees } \\
\text { Labourers }\end{array}$ & $\begin{array}{l}1.00 \\
1.14 \\
1.48^{* *} \\
1.21^{* *}\end{array}$ \\
\hline $\begin{array}{c}\text { Schrama } \\
{[33]}\end{array}$ & Cross-sectional & $1947-61,35-64$ & $\begin{array}{l}\text { Postal and } \\
\text { Telecommunication } \\
\text { Services } \\
(N=25,870)\end{array}$ & $\begin{array}{l}\text { Managers } \\
\text { Office personnel } \\
\text { Technical staff } \\
\text { Postal delivery men }\end{array}$ & $\begin{array}{l}1.00 \\
1.24 * * \\
1.08 \\
1.00\end{array}$ \\
\hline $\begin{array}{c}\text { vin Reek } \\
{[34]}\end{array}$ & Cross-sectional & $1959-61,40-64$ & $\begin{array}{l}\text { Total national } \\
\text { population } \\
(N=1,303.068)\end{array}$ & $\begin{array}{l}\text { Professionals a.o. } \\
\text { Own account workers and lower employees; } \\
\text { Labourers: }\end{array}$ & $\begin{array}{l}1.00 \\
1.15^{* *} \\
1.12^{* *}\end{array}$ \\
\hline $\begin{array}{c}\text { Mares } \\
{[35]}\end{array}$ & Longitudinal & $1953-80,40-65$ & $\begin{array}{l}\text { Civil servants } \\
\text { Amsterdam } \\
(N=1583)\end{array}$ & $\begin{array}{l}\text { Income level } 5 \text { (high) } \\
\text { Income level } 4 \\
\text { Income level } 3 \\
\text { Income level } 2 \\
\text { Income level I (low) }\end{array}$ & $\begin{array}{l}1.00 \\
1.10 \\
1.08 \\
1.15 \\
1.21\end{array}$ \\
\hline $\begin{array}{c}\text { Doornbos } \\
{[36]}\end{array}$ & Longitudinal & $1950-81,188$ & $\begin{array}{l}\text { National } 1932 \\
\text { birth cohort } \\
(N=78.505)\end{array}$ & $\begin{array}{l}\text { Educational level } 4 \text { (high) } \\
\text { Educational level } 3 \\
\text { Educational level } 2 \\
\text { Educational level } 1 \text { (low) }\end{array}$ & $\begin{array}{l}1.00 \\
1.15^{* *} \\
1.22^{* *} \\
1.49^{* *}\end{array}$ \\
\hline $\begin{array}{c}\text { Spruil } \\
{[37]}\end{array}$ & Longitudinal & $1960-85.40-49$ & $\begin{array}{c}\text { Town of Zutphen } \\
(N-457)\end{array}$ & $\begin{array}{l}\text { Professionals a.o. } \\
\text { Own account workers } \\
\text { Lower employees } \\
\text { Labourers }\end{array}$ & $\begin{array}{l}1.00 \\
2.25^{* *} \\
1.63 \\
2.07^{* *}\end{array}$ \\
\hline $\begin{array}{c}\text { Otten } \\
{[38]}\end{array}$ & Longitudinal & $1973-82,45-59$ & $\begin{array}{l}\text { Rotterdam } \\
(N=3365)\end{array}$ & $\begin{array}{l}\text { Professionals a.o. } \\
\text { Own account workers and lower employees } \\
\text { Labourers }\end{array}$ & $\begin{array}{l}1.00 \\
1.89^{* *} \\
2.14^{* *}\end{array}$ \\
\hline
\end{tabular}

- For longitudinal studies the given age range refers to the beginning of the study period.

+ Risk of dying relative to highest socio-economic group. Standardized for age except in the study of Otten.** Denotes significantly different from $1.00(P<0.05)$

\#xluding agricultural workers and miners respectively.

\$The death experience of this young cohort is principally formed in the years after 1965 
Table 3. Level of mortality from 10 largest causes of death in 1950-54 and or 1980-84. Indirectly standardised death rates*. all ages

\begin{tabular}{|c|c|c|c|c|}
\hline \multirow[b]{2}{*}{ Cause of death } & \multicolumn{2}{|c|}{$1950-54$} & \multicolumn{2}{|c|}{$1980-84$} \\
\hline & Males & Females & Males & Females \\
\hline Total mortality & 981.9 & 834.5 & 909.4 & 521.2 \\
\hline Stomach cancer & 53.3 & 34.3 & 21.9 & 9.5 \\
\hline Colon cancer & 12.2 & 15.2 & 17.2 & 15.2 \\
\hline Lung cancer & 31.3 & 3.8 & 97.0 & 8.1 \\
\hline Breast cancer & 0.2 & 31.1 & 0.3 & 34.4 \\
\hline Prostate cancer & 16.0 & not applic. & 21.3 & not applic. \\
\hline Diabetes mellitus & 9.1 & 18.9 & 7.6 & 9.1 \\
\hline Hypertensive disease & 16.5 & 22.3 & 4.2 & 4.1 \\
\hline Ischaemic heart disease & 129.3 & 78.8 & 212.2 & 94.2 \\
\hline Oeher heart diselase & 101.5 & 104.3 & 69.1 & 48.7 \\
\hline Cerebrovascular disease & 111.4 & 128.0 & 75.0 & 62.6 \\
\hline Arterial diseuses & 29.1 & 25.1 & 21.4 & 8.7 \\
\hline Influenza and pneumonia & 47.5 & 44.4 & 20.1 & 14.9 \\
\hline COLD & 24.7 & 14.3 & 40.7 & 8.7 \\
\hline Perinatal mortality & \multicolumn{2}{|c|}{32.6} & \multicolumn{2}{|c|}{$[0.4$} \\
\hline Traffic accidents & 22.9 & 5.7 & 18.6 & 6.4 \\
\hline Non-traffic accidents & 31.7 & 18.7 & 16.6 & 12.7 \\
\hline All other causes & 325.7 & 278.7 & 260.9 & 182.1 \\
\hline
\end{tabular}

- Deaths per 100,000 population. Indirectly standardised with mean national death rates by age for the period 1950-1984 as standard rates.

+Deaths per 1000 live. and stillbirths. Data are only available for both sexes together.

significant in only the following cases: colon cancer (females, 1952), lung cancer (females, 1952 and 1962), breast cancer (males, alt periods, and females, 1962), diabetes mellitus (males, 1982) and hypertensive disease (males and females, 1982).

The mortality level in a region and period was measured for each sex separately by Standardised Mortality Ratios (SMRs), with national age-specific death rates for $1950-84$ as the standard. For perinatal mortality we calculated comparable indices by dividing perinatal mortality rates by the national rate for 1950-84.

The socio-economic position of inhabitants of a region was measured by the variables on income, education and occupation that are presented in Table 4. In addition to variables that represent the average socio-economic position of the population, we included variables on the presence of population groups in the least favourable socio-economic situation. The socio-economic data were not sufficiently detailed to correct for regional differences in agedistribution. Regional differences with respect to unemployment and occupational status have diminished sizeably over time, but income and educational disparities have remained about the same.

It was found that the regional patterns of variation of the six socio-economic variables are strongly intercorrelated and that these patterns have hardly changed during the study period. The six variables were therefore combined into a single socio-economic index by means of factor analysis without rotation on all 21 available measures (6 variables times 4 periods less 3 measures missing) with the 39 regions as objects. The first factor explained $63 \%$ of all variation, while subsequent factors explained only 13 and $10 \%$ respectively. The pattern of loadings on the

Tirble 4. The selected socio-economic variables*

\begin{tabular}{lcccc}
\hline & \multicolumn{4}{c}{$\begin{array}{c}\text { Mean (coefficient of variation) } \\
\text { Loading on first unrotated factort }\end{array}$} \\
\cline { 2 - 5 } Variable & 1952 & 1962 & 1972 & 1982 \\
\hline Averuge income per & 1.15 & 2.31 & 4.95 & 12.17 \\
inhabitant (f lo00) & $(0.15)$ & $(0.15)$ & $(0.13)$ & $(0.12)$ \\
\% Incomes in lowest & 0.83 & 0.90 & 0.93 & 0.84 \\
caregoriest & 16.8 & 17.8 & 14.7 & 20.9 \\
& $(0.11)$ & $(0.09)$ & $(0.10)$ & $(0.08)$ \\
Average number of years & -0.72 & -0.63 & -0.67 & -0.60 \\
of education & no & 7.7 & 8.3 & 9.5 \\
& data & $(0.04)$ & $10.04)$ & $(0.04)$ \\
\% Inhabitants with only & & 0.90 & 0.93 & 0.87 \\
primary school & no & 57.2 & 42.9 & 31.3 \\
& data & $(0.08)$ & $(0.15)$ & $(0.15)$ \\
Number employees per & 30.9 & -0.90 & -0.90 & -0.71 \\
100 labourers. males & $(0.40)$ & 43.5 & 63.7 & no \\
& 0.85 & $(0.37)$ & $(0.29)$ & data \\
\% Males 15-64 year & 2.87 & 0.91 & 0.94 & 3.26 \\
unemployed & $(0.67)$ & 1.69 & 1.23 & $(0.37)$ \\
& -0.42 & -0.62 & -0.66 & -0.64 \\
\hline
\end{tabular}

"Sources: income data: publications of the Dutch Central Bureau of Statistics for 1950, 1960, 1969 and 1981 based on tax registries; unemployment data: published and unpublished data for 1951, 1960, 1970 and 1980 based on registries of Municipal Labour Offices; data on other variables: population censuses of 1947. 1960 and 1971 and the Labour Force Survey of 1979. 
first factor, given in Table 4, is essentially the same for all periods and indicates that the first factor can best be interpreted as the general socio-economic level of the regional population during the study period. The regional distribution of scores on the first factor (shown in Fig. 1) is characterised by the contrast between positive values in the centralwestern part of the Netherlands (the Randstad) and negative values in the country's periphery.

A number of alternative socio-economic indices has also been related to regional mortality differences. First, we considered separately the variables with the lowest loadings on the first factor (unemployment and the presence of low-income groups) in order to examine whether more specific socio-economic variables have distinct relationships with regional mortality levels. Secondly, socio-economic indices have been constructed for each period separately (by means of 4 factor analyses on period-specific variables) in order to account for slight systematic changes in the regional pattern of socio-economic differences. Application of these alternative indices did not show almost any new significant (changes in) socio-economic mortality differences, so that we will only report findings obtained with the socioeconomic index presented in Fig. 1.

This index has been related to regional mortality differences by means of unweighed, ordinary leastsquares regression analysis. SMRs were transformed to their natural logarithms so as to normalise the distribution of residuals. Two control variables were included: the percentage of the population living in large cities, and the percentage of the population belonging to the Roman-Catholic religious denomination. Average values for the entire study period were used. These variables were selected because it was found in preliminary analyses that they (I) represent to a large extent sociocultural and demographic characteristics of Dutch regions and (2) are important covariates of regional mortality differences in the Netherlands [47]. Controlling for these two variables influenced the outcomes of the regression analyses to a small degree. Regression analyses were performed for each period separately.

In an additional regression analysis, we examined whether the relationship between regional mortality differences and the socio-economic factor has changed significantly over time. Data for the four

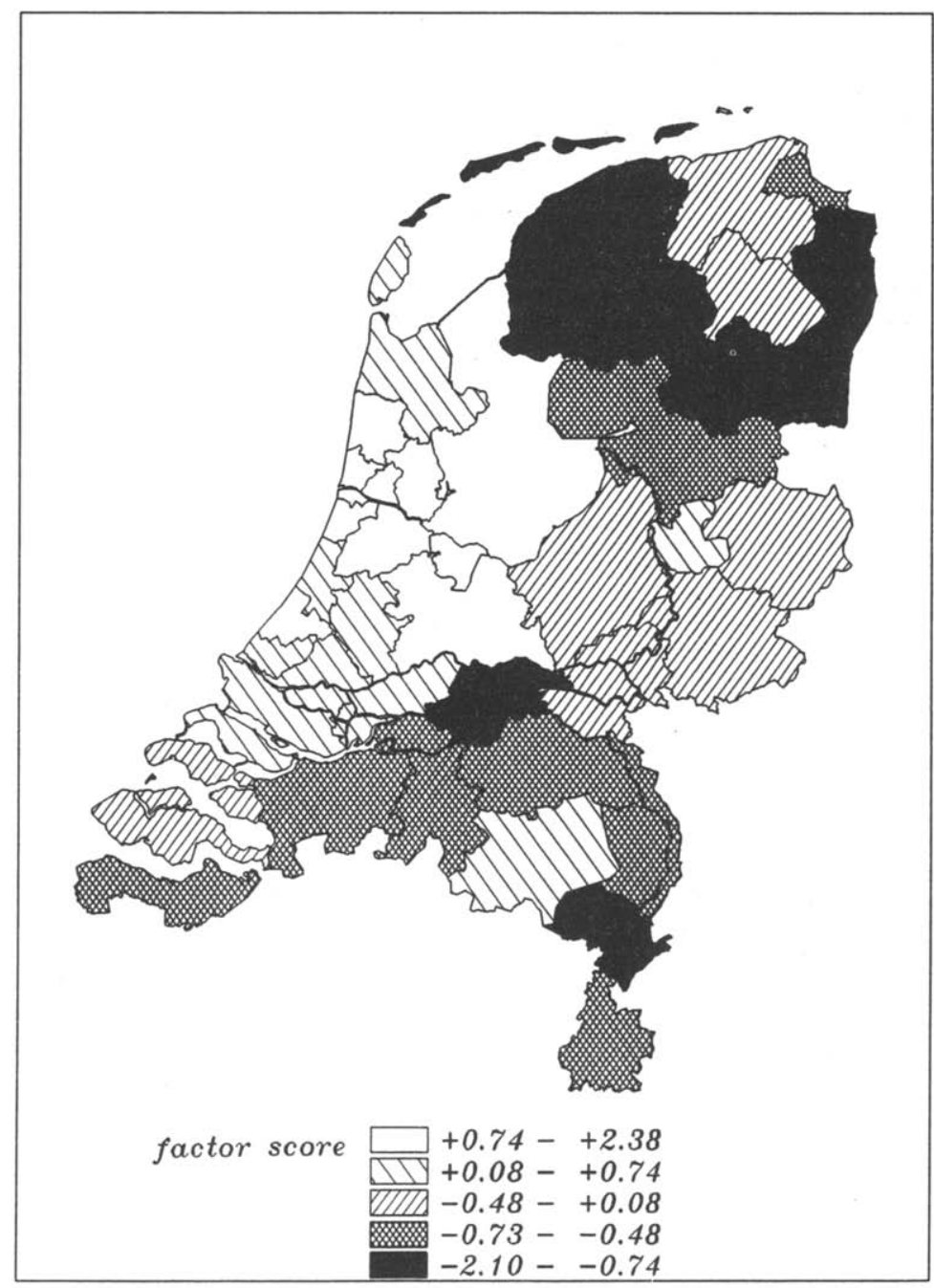

Fig. 1. Regional differences in the mean socio-economic level of the population. Score on the first factor. 
periods were merged into to a data set of 156 objects (39 regions times 4 periods). The corresponding regression model included the three regional variables (the socio-economic factor and the two control variables), a nominal variable indicating period and interaction terms for the period variable with the three regional variables. An $F$-test on the interaction between the period variable and the socio-economic factor was used to examine whether there is a significant difference between the regression coefficients for the four periods.

\section{RESULTS}

In Table 5 , the signs of the period-specific regression coefficients are shown. It is further indicated whether these coefficients differ significantly between the four periods. If there is a significant change for a particular cause of death, this is illustrated in Fig. 2. Fitted values of SMRs for regions with a score of -1.5 and +1.5 on the socio-economic factor (i.e. 1.5 standard deviations below respectively above the mean socio-economic level) are plotted for each of the four periods. These SMRs were calculated from the regression equations by filling in the national values for the control variables and the estimated regression coefficients.

Results for total mortality are given in the upper row of Table 5 and the upper part of Fig. 2(A). Among males, total mortality was positively related to the socio-economic factor in 1952 and 1962 , but the relationship had become negative in 1982 . For females, inverse relationships are found for all four periods but there is a weak and insignificant tendency towards more negative regression coefficients. Among both men and women, the mortality differences between regions with a high and a low socio-economic level were small in all periods.

Death rates for stomach cancer were higher in regions with a low socio-economic level during the whole study period. This association has not significantly or systematically changed. Other cancers were positively related to the socio-economic factor in all periods (except female colon cancer in 1982). For most cancers, socio-economic differentials have nonetheless been subject to significant changes, which are illustrated in Fig. 2(A). Positive relationships for colon cancer have disappeared and inverse relationships seem to emerge. A very large difference for lung cancer in 1952 among males has gradually and considerably diminished. The same happened among females during the $1970 \mathrm{~s}$, but without attaining statistical significance. A large positive difference for female breast cancer has diminished in the 1950s, but remained constant since then. The relationship between the socio-economic factor and prostate cancer mortality has not significantly or systematically changed.

Mortality differences for diabetes mellitus, ischaemic heart disease and CVA underwent similar changes which are illustrated in Fig. 2(B). Among males, a positive relationship became negative, while among females, the negative relationship arose earlier and has become more pronounced.

Trends for other cardiovascular diseases are less clear. No significant (changes in) relationships have been observed for hypertensive disease, which is probably due to random fluctuations caused by the small numbers of deaths from this disease. The absence of significant (changes in) relationships for other heart disease, one of the largest cause of death, indicates that changes in socio-economic mortality differences, if any, have been small. For arterial diseases, a positive relationship among males, and perhaps also among females, has emerged gradually (Fig. 2C).

In the early 1950s, the inhabitants of regions with a low socioeconomic level experienced higher death rates from influenza and pneumonia, COLD and perinatal mortality. For COLD and perinatal

Table 5. Relationship between cause-specific mortality and the socio-economic index in four periods, all ages

\begin{tabular}{|c|c|c|c|c|c|c|c|c|c|c|}
\hline \multirow[b]{3}{*}{ Cause of death } & \multicolumn{5}{|c|}{ Males } & \multicolumn{5}{|c|}{ Females } \\
\hline & \multicolumn{4}{|c|}{ Sign regression coefficient* } & \multirow{2}{*}{$\begin{array}{l}\text { Signific. } \\
\text { changet }\end{array}$} & \multicolumn{4}{|c|}{ Sign regression coefficient ${ }^{*}$} & \multirow{2}{*}{$\begin{array}{l}\text { Signific } \\
\text { changet }\end{array}$} \\
\hline & 1952 & 1962 & 1972 & 1982 & & 1952 & 1962 & 1972 & 1982 & \\
\hline Total mortality & + & + & $(+)$ & $\rightarrow$ & c & $(-)$ & - & $(-)$ & - & \\
\hline Stomach cancer & $(-)$ & $(-)$ & $(-)$ & - & & - & - & - & - & \\
\hline Colon cancer & $(+)$ & + & + & $(+)$ & $b$ & + & $(+)$ & $(+)$ & $(-)$ & $\star$ \\
\hline Lung cancer & + & + & + & $(+)$ & $\therefore$ & $(+)$ & $(+)$ & + & + & \\
\hline Breast cancer & \multicolumn{4}{|c|}{$\ddagger$} & & + & + & + & + & 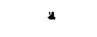 \\
\hline Prostite cancer & $(+)$ & $(+)$ & $(+)$ & + & & \multicolumn{4}{|c|}{ not applic. } & \\
\hline Diabetes mellitus & + & + & $(-)$ & $(-)$ & a & $(-)$ & $(-)$ & - & - & 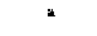 \\
\hline Hypertensive disease & $(+)$ & $(+)$ & $(+)$ & $(+)$ & & $(+)$ & $(-)$ & $(-)$ & $(-)$ & \\
\hline Jschaemic heart disease & + & $(+)$ & - & - & $\varepsilon$ & $(+)$ & - & - & - & c \\
\hline Other heart disease & $(+)$ & $(-)$ & $(-)$ & $(-)$ & & $(-1)$ & $(-)$ & $(-)$ & $(-)$ & \\
\hline Cerebrovascular disease & + & + & $(+)$ & $(-)$ & 2 & + & $(+)$ & $(+)$ & - & $a$ \\
\hline Arterial diseases & $(-)$ & $(-)$ & $(+)$ & + & $a$ & $(-)$ & $(-)$ & $(-)$ & $(+)$ & \\
\hline Influenza and preumonia & - & $(+)$ & $(+)$ & $(+)$ & $b$ & - & $(-)$ & $(+)$ & $(+)$ & $b$ \\
\hline COLD & $(-)$ & $(-)$ & $(-)$ & $(-)$ & & - & - & - & $(-)$ & \\
\hline Perinatal morlality & - & - & - & $(-)$ & $\$$ & & & & & \\
\hline Trufic accidents & $(-)$ & - & - & - & 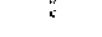 & $(-)$ & - & - & - & \\
\hline Non-traffic accidents & $(-)$ & $(-)$ & $(+)$ & $(+)$ & & $(-)$ & + & + & $(-)$ & \\
\hline All oiher causes & + & + & + & $(+)$ & & $(-)$ & $(-)$ & $(+)$ & $1+1$ & \\
\hline
\end{tabular}

- Regression analysis of the natural logarithm of SMRs on the socio-economic factor, controlling for $\%$ inhabitants in large cities and $\%$ inhabitants Roman-Catbolic. Catried out for each period separately. Regression coefficients between parentheses if not significant at the $10 \%$ level.

t Test on differences in regression coefficients between the four periods (for calculation see text). ${ }^{\mathrm{d}} P<0.10 .{ }^{b} P<0.05 .{ }^{\mathrm{s}} P<0.01$. + Excluded because of non-significant regional mortality differences in all periods. \$Results for perinatal mortality refer to both sexes together. 

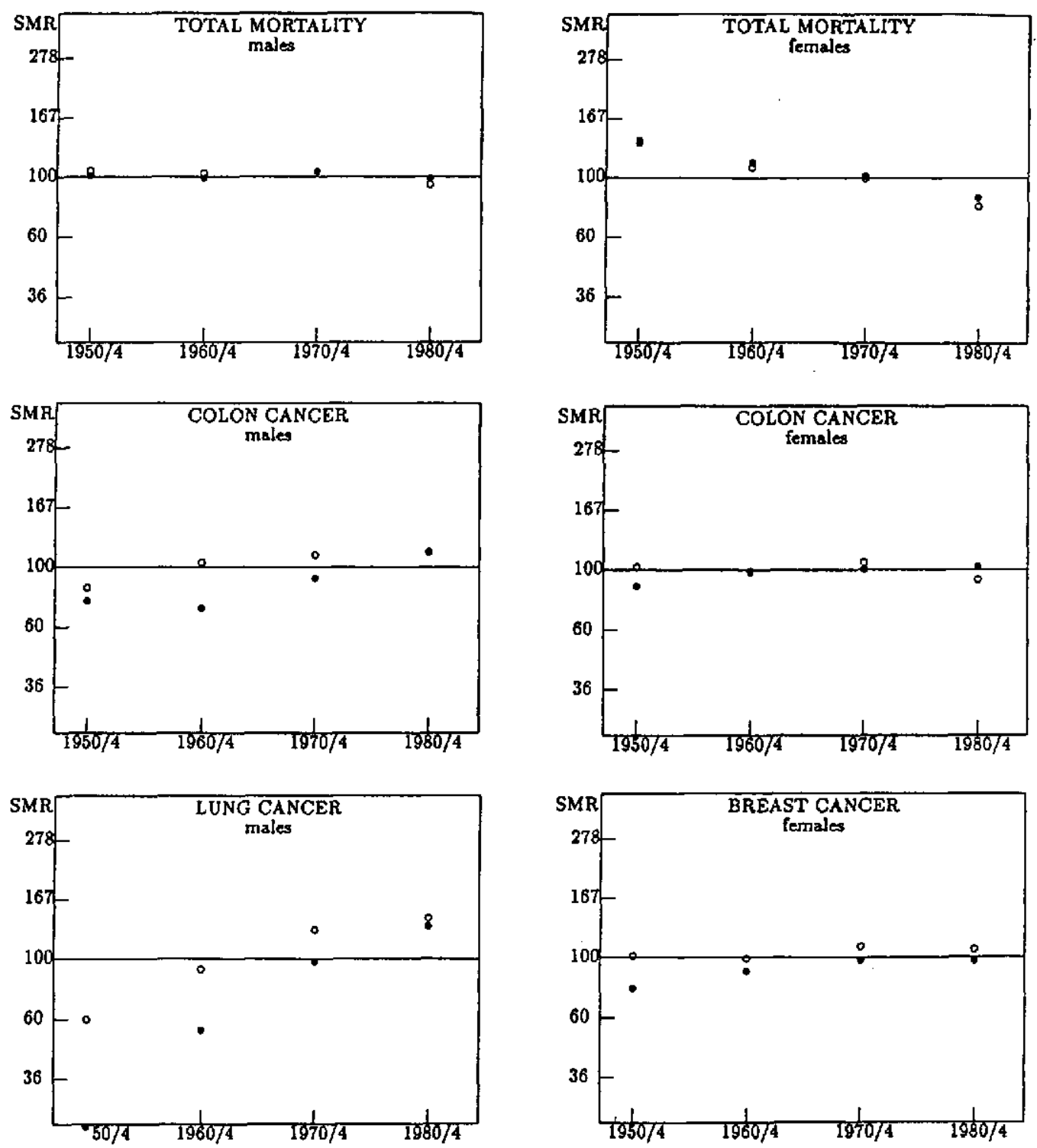

Fig. 2(A)

Fig. 2. (A) Mortality level in four periods at a high (O) and a low (O) score on the socio-economic index [Expressed as SMRs with national mortality rates for 1950-84 as the standard. Estimation on the basis of the results of the regression analysis with the socio-economic index set at +1.5 (for 0 ) and -1.5 (for 9 ). and the control variables at their mean values.]: total mortality and some cancers. 

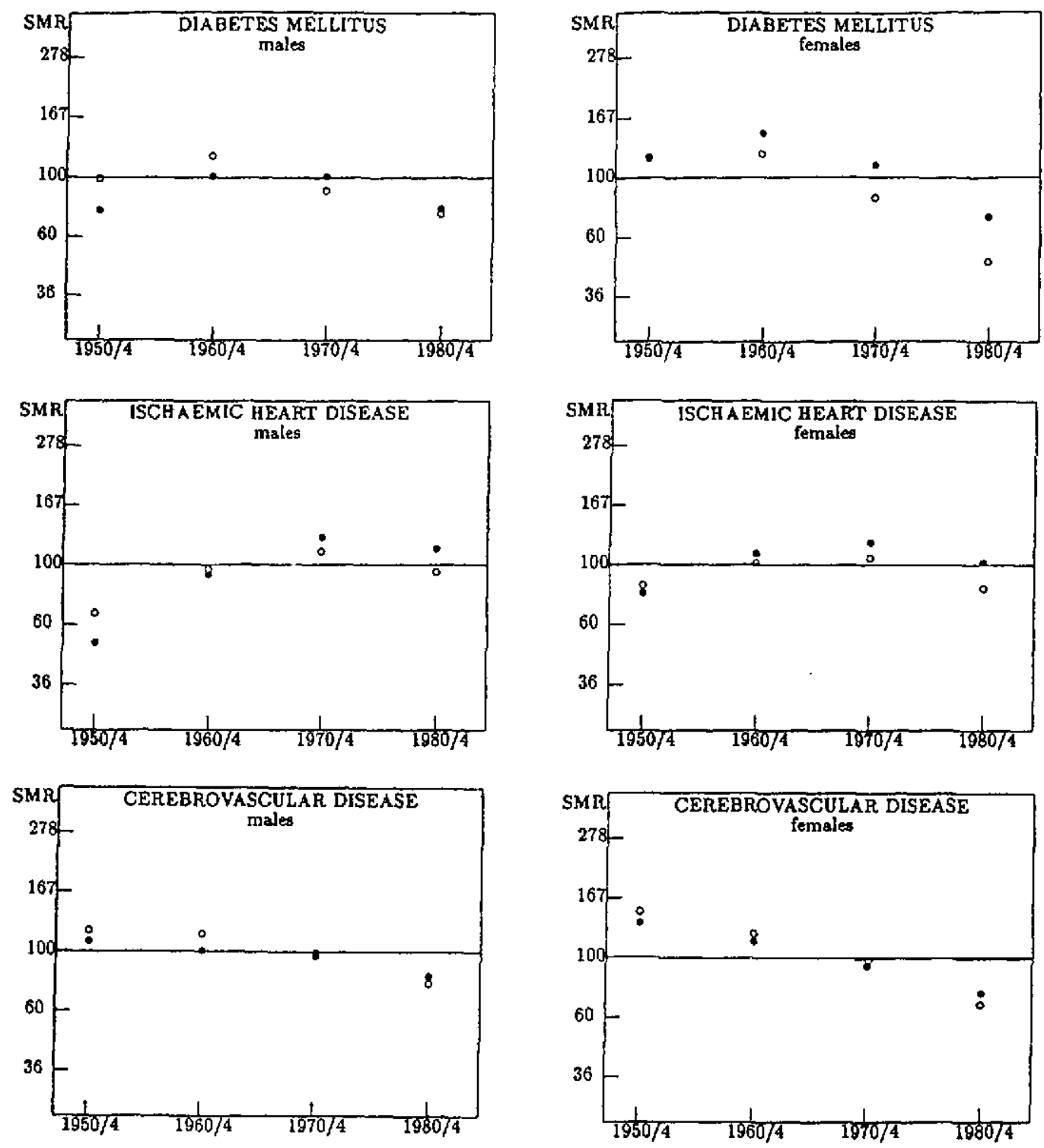

Fig. 2(B)

Fig. 2. (B) Mortality level in four periods at a high $(O)$ and a low (O) score on the socio-economic index: selected causes of death. 

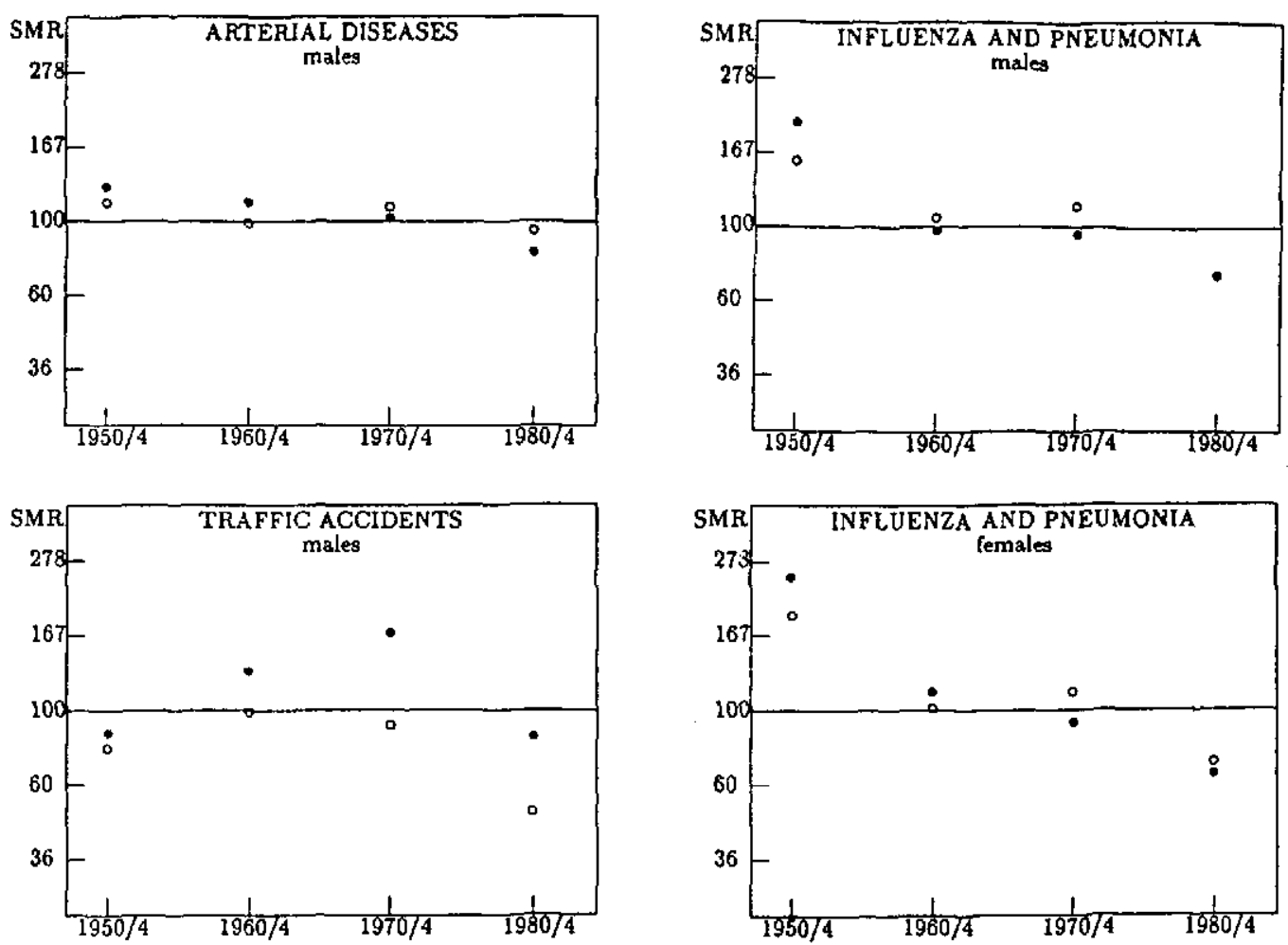

Fig. 2(C)

Fig. 2. (C) Mortality level in four periods at a high (O) and a low $(O)$ score on the socio-economic index: selected causes of death.

mortality, this association has not changed significantly in subsequent decades, while for influenza and pneumonia this association disappeared within one decade (Fig. 2C).

For traffic accidents, a negative association was found for all four periods, but changed nonetheless significantly for males: an initially moderate difference became very large in the 1950s and 1960s and then remained constant (Fig. 2C). The pattern of change for females was similar but not significant. No significant changes were observed for socio-economic differences in non-traffic accident mortality.

Mortality differences for all other causes together were small and did not change significantly, which implies that this group of causes of death does not play a predominant role in explaining (trends in) the relationship between total mortality and the socioeconomic factor.

In the Netherlands as a whole, postwar mortality rates for diabetes mellitus. ischaemic heart diseases and traffic accidents have developed in an epidemic fashion: an initial mortality rise levelled off and turned into a mortaiity decline. Figure $2(B)$ and $2(C)$ indicate that for each cause of death the onset of the mortality decline first started in regions with a high socio-economic level. while the trend in low-level regions lagged behind (see also [48]). This 'timing lag' seems to have contributed to the development of a (larger) excess mortality in regions with a low socioeconomic level. The evolution of socio-economic differences in mortality from colon cancer, lung cancer and CVA may also in part be due to the occurrence of a timing lag. However, this cannot convincingly be assessed because it is not possible to determine the exact timing of changes in mortality trends for these diseases.

Comparison with trends in socio-economic mortality differences in England and Wales

The findings of this regional analysis resemble the observations on trends in social class differences in England and Wales in a number of ways: associations for total mortality have become (more) negative in the postwar period-especially among males; the mortality gradient for diabetes mellitus, ischaemic heart disease and cerebroyascular disease changed from positive to negative; for several other causes of death too, e.g. colon cancer, breast cancer and traffic accidents, trends in differential mortality in the Netherlands and in England and Wales were practically the same; in neither country the mortality gradient for other heart disease seems to have changed considerably.

However, some notable discrepancies were found too: for causes of death that were inversely related to socio-economic indicators in the early $1950 \mathrm{~s}$ (stomach cancer, respiratory diseases, perinatal mortality), socio-economic differentials did not become consistently or significantly wider in our study, whereas this happened in England and Wales to a number of these diseases. Another deviant finding of our study is the positive relationship between the 
socio-economic level and male mortality in 1952 and 1962 for all causes of death together and for lung cancer in particular.

\section{DISCLSSION}

For all-cause mortality as well as for the largest causes of death, we attempted to answer the question whether socio-economic mortality differences in the Netherlands have developed in a similar way as in England and Wales. This study shares its comparative perspective with studies like those comparing the English situation with that in the United States [49], France [50], Japan [51] and Hungary and the Scandinavian countries $[25,52]$. But unlike these studies, we did not focus on the magnitude of socioeconomic mortality differences at one moment in time, but on the way in which such differences have developed over time.

As a review of individual-level studies yielded only very limited evidence on trends in mortality differences in the Netherlands, we carried out a geographical study. The use of regional data enabled us to study a wide range of causes of death, to study females as well as nales and to cover the complete Dutch population (e.g. all age-groups). Results for different moments in time could be made comparable through the use of uniform cause-of-death groups. one single socio-economic indicator and a standard regression procedure.

The findings of this regional analysis resemble the observations on trends in social class differences in England and Wales in various ways. However, some notable discrepancies were found too. In contrast to the situation in England and Wales, the mortality gap for stomach cancer, respiratory diseases and perinatal mortality did not become consistently or significantly wider in our study. Our failure to show widening mortality differences may in part be attributable to the effects of chance fluctuations in regional mortality levels for small causes of death. However. this cannot be the entire explanation as differentials for equally small causes of death like diabetes mellitus and traffic accidents have significantly and considerably changed.

Another deviant finding of our study is the positive relationship between socio-economic level and male mortality in 1952 and 1962, for all causes of death together and for lung cancer in particular. This may reflect real differences between the two countries. However, individuat-level studies on the Netherlands before 1965 found inverse (although not consistent) mortality gradients [32-34], so that the deviant 'positive' findings of our study may be attributable to characteristics of our method.

A first aspect of our method is that we considered all age-groups together, whereas studies at the individual level are generally limited to younger age-groups and in particular to men at working age. Positive associations were also found, however, when we analysed mortality in the age-group 15-64 years only (figures not shown here).

A second aspect of our method relates to the possibility of confounding by migration. If interregional migration in the Netherlands was selective to health (migrants being healthier, as found in
France and England [53]), a net outmigration from regions with a high socio-economic level would have resulted in higher mortality levels in these regions. and would have biased our findings towards more positive associations. However, we found that until the 1970s a net immigration instead of outmigration was experienced by regions with a high socio. economic level (in all age groups).

A crucial characteristic of our method is the use of data at the aggregate (regional) level. which raises the question whether the results from this level of analysis can be inferred to the individual level. Crosslevel inference can be biased by the operation of geographical confounders or effect modifiers $[46,54]$. It should be recalled that socio-economic differences between Dutch regions are dominated by a centre. periphery contrast (Fig. 1). A host of other societal, cultural and/or environmental factors may accompany this contrast [55], and such factors may have acted as confounders or effect modifiers. The strongly deviant findings for lung cancer suggest that some of these factors are related to lung cancer. For example, the positive mortality gradient for lung cancer mortality until the 1970 s may in part be related to the higher levels of air contamination in the country"s centre in the 1960s and before [56]. But a more likely explanation relates to tobacco consumption among men. While around 1960 cigarette smoking was already more prevalent among lower social classes $[37,57]$, it was still less prevalent in peripheral regions [58]. Cigarette smoking was probably introduced slowly in the periphery, because until the 1950 s local communities often resisted to changes that originated from the country's centre $[59,60]$.

If cross-level inference is indeed biased in the case of all-cause and lung cancer mortality in the $1950 \mathrm{~s}$ and 1960s, an important question is whether it also affected our results with respect to the evolution of differential mortality over time. Unfortunately, for many causes of death there are no data at the individual level that permit to evaluate the effect of ecologic bias. Data are however available for male mortality from all causes together, for lung cancer and for ischaemic heart disease, and it is comforting to note that in all three cases the evidence from individual-level data indicates a similar trend toward (more) negative mortality differentials as found in the regional study (see review in Introduction).

From the foregoing discussion it can be concluded that socio-economic mortality differences in the Netherlands and England and Wales have probably developed similarly in various respects. In particular, it is apparently not a uniquely English phenomenon that some former 'high class' diseases have become 'low class' diseases, and thus have contributed considerably to widening mortality differentials. This conclusion is sustained by studies from France, Hungary and the United States, which observed the emergence of inverse mortality gradients for various diseases $[22,23,31]$.

Further studies on other countries would permit to answer the question whether the widening of the mortality gap between English social classes, and the underlying changes for specific causes of death, represents a generalized phenomenon in highly developed societies. Their results would suggest whether 
widening mortality differences should principally be explained by idiosyncracies of some societies or whether inherent and structural characteristics of highly developed societies play a decisive role.

A structural characteristic mentioned by Morgenstern [29] is that upper social classes are most able to exert control effectively over their lifestyle and environment and, as a consequence, can adapt more quickly to the continuous changes in modern society. This applies probably also to mortality related changes, as our analysis suggests that mortality changes first occur in upper social classes. This 'timing lag' in mortality trends between social classes may have contributed to the widening of the mortality gap between social classes. It may have done so especially in the 1960s and 1970s, when more favourable mortality trends set in for large causes of death such as lung cancer and ischaemic heart disease.

Several risk factors may be involved. Massive smoking cessation started first among higher social classes in the 1950 s and 1960 s $[19,24,57,61]$. Favourable changes in diet and serum cholesterol levels during the 1960s and 1970s also first occurred among the upper social classes $[19,62,63]$. The changing social class distribution in CVA may be indicative of changing differences in the prevalence of hypertension $[29,64]$, but may also reflect social class differences in the application of effective hypertension management techniques that were introduced in the late 1960s $[65,66]$. Further studies on trends in risk factor differences may provide new insights into the dynamic nature of socio-economic mortality differences.

Acknowledgements - This study was supported by a grant from the Ministry of Welfare, Public Health and Culture. Rijswijk, the Netherlands. The mortality data were supplied by the Dutch Central Bureau of Statistics. Unemployment data for 195L. 1960 and 1970 have been acquired with the help of the Netherlands Economic Institute.

\section{REFERENCES}

1. Antonovsky A. Social class. life expectancy and overall mortality. Milbank Meml Fund Q. 45, 31, 1967.

2. Antonovsky A. and Bernstein J. Social class and infant mortality. Soc. Sci. Med. 11, 453, 1977

3. Aiach P., Carr-Hill R.. Curtis S. et al. Les Inégalités Sociales de Santé en France et en Grand-Bresagne. Inst. Nat. de la Santé et de la Recherche Medicale, Paris, 1989.

4. Aiach P. and Carr-Hill R. Inequalities in health: the country debate. In Health Inequalities in European Coumries (Edited by Fox J.), p. 19. Gower, Aldershot, 1988

5. World Health Organisation. The Burden of Social Inequities. WHO. Copenhagen, 1984.

6. UNPD WHO/CICRED. Socio-economic differential mortality in industrialized societies. Reports No. I to 5 . Paris, 1981-1989.

7. Townsend P.. Davidson N. and Whitehead M. Inequalities in Health (The Black Report \& The Health Diride). Penguin Books, London. 1988.

8. Hart N. Inequalities in health: the individual versus the environment. J.R. Statist. Soc. 149, 228, 1986

9. Wilkinson R. G. (Ed.) Socio-economic differences in mortality: interpreting the data on their size and trends. In Class and Heath, Research and Longitudinal Data. p. I. Tavistock. London. 1986.
10. Ilsley R. Occupational class, selection and inequalities in health: rejoinder to Richard Wilkinson's repiy. Q. J. Soc. Affairs 3, 213, 1987.

11. Pamuk E. R. Social class inequality in mortality from 1921 to 1972 in England and Wales. Popul. Siud. 39, 17, 1985.

12. Koskinen $\mathrm{S}$. Time trends in cause-specific mortality by occupational class in England and Wales. In Proceedings of the IUSSP Conference at Florence. p. 1, June 1988. IUSSP. Florence, 1988.

13. Marmot M. G. and McDowall M. E. Mortality decline and widening social inequalities. Lancet 2, 274, 1986.

14. Registrar General. Occupational Mortality. Decennial Supplement for Great Britain, 1979-80, 1982-83. HMSO, London. 1986.

15. Blaxter M. Social class and health inequalities. In Equalities and Inequalities in Health (Edited by Carter C. O. et al.). p. 111. Academic Press, London, 1975.

16. Pamuk E. R. Social-class inequality in infant mortality in England and Wales from 1921 to 1980. Eur. J. Popul. 4, 1,1988 .

17. Halliday M. L. and Anderson T. W. The sex differential in ischaemic heart disease: trends by social class 1931 to 1971. J. Epidem. Commun. Hith 33, 74, 1979.

18. Logan W. P. D. Cancer Mortality by Occupation and Social Class 1851-197J. HMSO, London, 1982.

19. Marmot M. G., Adelstein A. M., Robinson N. et al. Changing social-class distribution of heart disease. Br. med. J. 2, $1109,1978$.

20. Hems G. Associations between breast-cancer mortality rates, child-bearing and diet in the United Kingdom. Br. J. Cancer 41, 429. 1980.

21. Mackenbach J. P., Stronks K. and Kunst A. E. The contribution of medical care to inequalities in health: differences between socio-economic groups in decline of mortality from conditions amenable to medical intervention. Soc. Sci. Med. 29, 369, 1989.

22. Desplanques G. La Mortalité des Adultes: Résultats de 2 Études Longitudinales (Période 1955-1980). INSEE, Paris, 1984.

23. Klinger A. Socio-economic differential mortality in Hungary. In Socio-Economic Differential Mortality. Report of the 4th Meeting in Hungary, p. 17. UNPD WHO/CICRED/Hung. Stat. Office, 1986.

24. Feldman J. J., Makuc D. M., Kleinman J. C. et al. National trends in educational differentials in mortality. Am. J. Epidem. 129, 919, 1989.

25. Valkonen $\mathrm{T}$. Social inequality in the face of death. In Plenaries of the European Population Conference at Jytüskylä, p. 20l, 1987.

26. Dinh $Q$. C. Le relief social de la mortalité infantile: des écarts qui satténuant. Données Sociales. In press.

27. Hansen-Koenig D., Manciaux M. and Deschamps J.-P. La mortalité périnatale au Grand-Duché de Luxembourg: evolution de 1969 à 1979. Ret. Epidém. Santé Publ. 31, 129, 1983.

28. Wing S. Social inequalities in the decline of coronary mortality. Am. J. publ. Hlth 78, 1415, 1988.

29. Morgenstern $H$. The changing association between social status and coronary heart disease in a rural population. Soc. Sci. Med. 14A, 191, 1980.

30. Valkonen T., Javanainen M.. Koskinen S. et al. Research on socio-economic differential mortality at the Department of Sociology. University of Helsinki. Paper presented at the Sth Meeting of the UNDP I WHO CICRED Meeting on Socio-Economic Differential Mortality in Industriali-ed Societies. Paris, 6-8 Dec., 1989.

31. Lerner $M$. and Stutz R. N. Have we narrowed the gaps between the poor and the non-poor? Part Il: Narrowing the gaps, 1959-1961 to 1969-1971: mortality. Med. Care $15,620,1977$. 
32. Wolft $P$. de and Meerdink J. Mortality rates in Amsterdam according to profession. In Proceedings of the World Population Conference 1954, Vol. I. p. 51, Rome, 31 Aug.-10 Sept. 1954. United Nations, New York. 1954.

33. Schrama P. G. M. Bedrij/sgeneeskunde en Volks. gezonheid. Van Gorcum, Assen. 1963.

34. Reek J. van and Zutphen W. M. van. Sterfte naar sociale klasse bij volwassenen in Nederland sinds de negentiende eeuw. Betolking Gezin 2, 179, 1985.

35. Mares N. E. H. M., Aben D. J. M., Schouten E. G. et al. Inkomen en sterfte; resultaten van 25 jaar vervolgonderzoek bij mannelijke Amsterdamse ambtenaren. Ned. Tijdschr. Geneeskd. 132, $1109,1988$.

36. Doornbos G. and Kromhout D. Opleiding en sterfte van 18-jarige Nederlandse mannen gedurende een follow-up periode van 32 jaar. Technical Report, State University at Leiden. 1989.

37. Duijkers T. J., Kromhout D., Spruit I. P. et al. Intermediating risk factors in the relation between socioeconomic status and 25-year mortality (the Zutphen Study). Int. J. Epidem. 18, 658, 1989.

38. Otten F., Mendes de Leon C. F. and Appels A. De samenhang tussen sociaal-economische status, gezondheidsopvattingen, risicofactoren. cardiale mortaliteit en sterftekans. Technical Report. State University at Limburg, 1989.

39. Haas-Posthuma J. H. de. Perinatale Sterfte in Nederland. Van Gorcum, Assen, 1962.

40. Haas-Posthuma J. H. de and Haas J. H. de. Infant loss in The Netherlands. Vital and Health Statistics. Analytical Studies. NCHS, Series 3, No. I1. U.S. Department of Health. Education and Welfare, Washington, DC, 1968.

41. Doornbos J. P. R. and Nordbeck H. J. Civil registration data. In Perinatal Mortality. Obstetric Risk Factors in a Community of Mixed Ethnic Origin in Amsterdam, p. 67. ICG Printing BV, Dordrecht, 1985.

42. Versluys J. J. Cancer and occupation in the Netherlands. Br. J. Cancer 3, 161, 1949.

43. Wassink W. F. Ontstaansvoorwaarden voor longkanker. Ned. Tijdschr. Geneeskd. 92, 3732, 1948.

44. Poppel F. van. A review of research into the socioeconomic determinants of mortality in the Netherlands since the second world war. In Social and Differential Mortality in Industrial Countries. Report of the First Meeting, p. 67, Geneva, July 1980. UNPD/WHO/ CICRED, Paris, 1981.

45. Maas P. van der, Habbema J. D. F., Lau-Ijzerman A. et al. Socio-economic mortality differences between districts in the city of Amsterdam. In Social and Differential Mortality in Industrial Countries. Report of the First Meeting, p. 79, Geneva, July 1980. UNPD/ WHO/CICRED, Paris, 1981.

46. Greenland S. and Morgenstern H. Ecological bias, confounding, and effect modification. Int. J. Epidem. 18, $269,1989$.

47. Kunst A. E., Looman C. W. N. and Mackenbach J. P. Regionale sterfteverschillen en sociaal-economische indicatoren. Technical Report. Erasmus University Rotterdam, 1989.
48. Mackenbach J. P., Looman C. W. N. and Kunst A. E. Geographic variation in the onset of decline of male ischemic heart disease mortality in the Netherlands. Am. J. publ. Hlish 79, 1621, 1989.

49. Guralnick J. Socio-economic differences in mortality by cause of death: United States, 1950 and England and Wales, 1949-53. In Proceedings of International Population Conference. p. 287. Ottawa, 1963. IUSSP, Liege, 1964.

50. Leclerc A., Lert $F$, and Goldberg $M$. Les inequalités sociales devant la mort en Grand-Bretagne et en France. Soc. Sci. Med. 19, 479. 1984.

51. Kagamimori S., Iibuchi Y. and Fox J. A comparison of socio-economic differences in mortality between Japan and England and Wales. Wld Hlth Statist. Q. 36, 119 , 1983.

52. Vågerö $D$. and Lundberg $O$. Health inequalities in Britain and Sweden. Lancet 2, 35, 1989.

53. Fox A. J, and Goldblatt P. O. Socio-Demographic Mortality Differentials from the OPCS Longitudinat Study 1971-75 (Series LS No. 1). HMSO, London. 1980.

54. Firebaugh G. A rule for inferring individual level relationships from aggregate data. Am. Soc. Rev. 43, $557,1978$.

55. Seers D., Schaffer B. and Kiljunen M. (Eds) Underdeveloped Europe: Studies in Core-Periphery Relations. The Harvester Press, Hassocks, 1979.

56. Biersteker K. Verontreinigde Lucht. Van Gorcum Assen, 1966.

57. Reek J. van. Rookgedrag in Nederland van 1958-1982. Tijdschr. Alcohol Drugs 9, 99, 1983.

58. Meinsma L. Longkankersterfte in Nederland. Ned. Tijdschr. Geneeskd. 107, 1432, 1963.

59. Hofstee E. W. Rural Life and Rural Welfare in the Netherlands. Government Printing and Publishing Office, The Hague, 1957.

60. Instituut voor Sociaal Onderzock van het Nederlandse Volk. Ontwikkelingspebieden. Technical Report, 1957.

61. Reek J. van and Adriaanse H. Cigarette smoking cessation rates by level of education in five western countries [Letter]. Int. J. Epidem. 17, 474, 1988.

62. Jones J. L. Are health concerns changing the American diet? Natn. Food Situat. 159, 27, 1977.

63. Nat. Center for Health Statistics-Nat. Heart, Lung, and Blood Inst. Collab. Lipid Group. Trends in serum cholesteroi levels among US adults aged 20 to 74 years: data from the National Health and Nutrition Examination Surveys, 1960 to $1980 . J$. Am. med. Ass. 257, 937, 1987.

64. Miall W. E. Follow-study of arterial pressure in the population of a Welsh mining valley. Br. med. J. 2, $1204,1959$.

65. Shulman N.. Cutter G., Daugherty R. et al. Correlates of attendance and compliance in the Hypertension Detection and Follow-up Program. Controlled Clin. Trials 3, 13, 1982.

66. Kottke T. E., Young D. T. and McCall M. M. Effect of social class on recovery from myocardial infarction. Minn. Med. 63, 590, 1980. 